Institute of $\mathbf{F}_{\text {ood and }} \mathbf{A}_{\text {gricultural }} \mathbf{S}_{\text {ciences }}$

\title{
2003 Handbook of Employment Regulations Affecting Florida Farm Employers and Workers: Emergency Planning and Community Right-to-Know [State] ${ }^{1}$
}

\author{
Leo C. Polopolus, Michael T. Olexa, Fritz Roka, and Carol Fountain ${ }^{2}$
}

\section{Purpose}

To facilitate awareness and emergency planning regarding the potential chemical hazards in local communities.

\section{Program}

This law seeks to encourage emergency planning efforts at the state and local levels and to increase the public's access to information about the potential chemical hazards that may exist in their communities.

Any facility that produces, uses, or stores extremely hazardous substances (EHS) in excess of the Threshold Planning Quantity (TPQ) must comply with some or all requirements of this law. In addition, all businesses that have a spill or an unauthorized release of an EHS in excess of the Reportable Quantity (RQ) must immediately report such spills or releases.

\section{Who Must Comply}

If you have restricted use and/or danger labeled pesticides or chemicals on your property in sufficient quantities, you may need to comply with this law.

\section{Responsible Agency}

State Emergency Response Commission

1. This is EDIS document FE395, a publication of the Department of Food and Resource Economics, Florida Cooperative Extension Service, Institute of Food and Agricultural Sciences, University of Florida, Gainesville, FL. Published July 2003. This information is included in Circular 1200, Handbook of Employment Regulations Affecting Florida Farm Employers and Workers. First published February 1992 as Circular 1043 . Revised December 2002 as Circular 1200. Please visit the EDIS website at http://edis.ifas.ufl.edu.

2. Leo C. Polopolus, Professor Emeritus, Department of Food and Resource Economics, University of Florida, Gainesville, FL; Michael T. Olexa, Professor, Department of Food and Resource Economics, University of Florida, Gainesville, FL; Fritz Roka, Associate Professor, Department of Food and Resource Economics, Southwest Florida Research and Education Center, Immokalee, FL; and Carol Fountain, Assistant Editor, Department of Food and Resource Economics, University of Florida, Gainesville, FL; Florida Cooperative Extension Service, Institute of Food and Agricultural Sciences, University of Florida, Gainesville, FL.

This document is designed to provide accurate, current, and authoritative information on the subject. However, since the laws, administrative rulings, and court decisions on which it is based are subject to constant revision, portions of this publication could become outdated at any time. This publication is distributed with the understanding that the authors are not engaged in rendering legal or other professional advice, and the information contained herein should not be regarded as a substitute for professional advice. For these reasons, the utilization of these materials by any person constitutes an agreement to hold harmless the authors, the Institute of Food and Agricultural Sciences, and the University of Florida for any liability claims, damages, or expenses that may be incurred by any person as a result of reference to or reliance on the information contained in this publication.

The Institute of Food and Agricultural Sciences is an equal opportunity/affirmative action employer authorized to provide research, educational information and other services only to individuals and institutions that function without regard to race, color, sex, age, handicap, or national origin. For information on obtaining other extension publications, contact your county Cooperative Extension Service office. Florida Cooperative Extension Service/Institute of Food and Agricultural Sciences/University of Florida/Christine Taylor Waddill, Dean. 
2555 Shumard Oak Boulevard

Tallahassee, FL 32399-2100

(850) 413-9970

1-800-635-7179 (Florida only)

http://www.dca.state.fl.us/cps/SERC/serc.htm 